\title{
PERTANGGUNGJAWABAN ATAS KERUSAKAN BARANG PADA JASA EKSPEDISI PELAYANAN SATU MALAM PADA PERUSAHAAN TIKI *
}

\author{
Oleh: \\ Made Widya Hatman Yogaswara** \\ Made Maharta Yasa, SH.,MH*** \\ Program Kekhususan Hukum Bisnis \\ Fakultas Hukum Universitas Udayana
}

\begin{abstract}
Abstrak
Perusahaan pengiriman barang Tiki merupakan salah satu perusahaan raksasa pengiriman barang melalui jasa ekspedisi di Indonesia. Sebagai perusahaan pengiriman terbesar di Indonesia, maka penting bagi Tiki untuk membenahi sistem yang ada pada perusahaannya demi menjaga loyalitas konsumen. Pertanggung jawaban dan ganti rugi pada Tiki menjadi sebuah persoalan sehingga penting untuk disusun sebuah penelitian singkat yang dapat menjelaskan kelemahan yang terdapat pada perusahaan Tiki di Indonesia. Rumusan masalah jurnal ini adalah pertama, Bagaimanakah tanggung jawab atas kerugian terhadap ekspedisi pelayanan satu malam apabila terjadi keterlambatan? dan kedua, Bagaimana bentuk penyelesaian atas kerugian dari jasa ekspedisi itu ? Tujuan penyusunan adalah Untuk mengetahui bentuk tanggung jawab yang diberikan kepada konsumen serta bentuk ganti rugi yang diberikan kepada konsumen saat menggunakan jasa pengiriman tersebut Metode yang digunakan merupakan metode penelitian hukum empiris dengan pendekatan konseptual, perundang-undangan dan pendekatan fakta empiris. Hasil akir dari jurnal ini adalah pertama, pelayanan yang diberikan oleh Tiki belum sepenuhnya memberikan pertanggung jawaban sedangkan kedua, aspek ganti rugi yang diberikan juga perlu dibenahi kembali.
\end{abstract}

Kata Kunci : Etika Pariwara, Over Night Service, Pengiriman, Tiki.

\section{Abstract}

Tiki freight forwarding company is a giant freight forwarder through expedition services in Indonesia. As the largest shipping company in Indonesia, it is important for Tiki to fix the existing system in the company to maintain customer loyalty. Liability and compensation on Tiki is a problem so it is important to develop a short research that can explain the weaknesses found in Tiki companies in Indonesia. The formulation of this journal problem

\footnotetext{
*Tulisan ini merupakan makalah ilmiah di luar ringkaan skripsi

**Made Widya Hatman Yogaswara adalah mahasiswa Fakultas Hukum Universitas Udayana Korespondensi : ewidfl@gmail.com

*** Made Maharta Yasa SH.,MH adalah dosen Fakultas Hukum Universitas Udayana. Korespondensi: mdmahartayasa@gmail.com
} 
is first, Is the Tiki give responsibility for damage and late delivery service? And secondly, how the Tiki give compensation has claim for damage and late delivery service? The purpose of the preparation is to analyze the form of responsibility given to consumers and the form of compensation provided to consumers when using the shiping service. The method used is a normative legal research method with a conceptual approach, legislation and a case approach. The result of the end of this journal is first, the service in Tiki not yet fully providing responsibility and aspects of compensation provided also need to be addressed.

Keywords: Pariwara Ethics, Over Night Service, Delivery, Tiki 


\section{Pendahuluan}

\subsection{Latar Belakang}

Aktifitas pengiriman barang di Indonesia merupakan sebuah rutinitas yang dilaksanakan oleh masyarakat terutama bagi seorang pengusaha. Pengiriman barang yang telah mengalami proses konvensionalitas menjadi sebuah lapangan usaha terbaik bagi seorang pelaku usaha untuk mendapatkan penghasilan yang melimpah. Akan tetapi, pengiriman barang cenderung dipermasalahkan ketika terjadi kecacatan pada barang yang dikirimkan ataupun pelayanan yang ditawarkan tidak sesuai dengan yang diiklankan. Erni Setyowati dan Widyani menjelaskan bahwa terdapat beberapa faktor yang mempengaruhi loyalitas dari seorang pelanggan diantaranya adalah harga, merek dan pelayanan. ${ }^{1}$

Kualitas pelayanan oleh perusahaan Tiki juga disoroti sebab tidak memberikan pelayanan yang berintegritas ketika dilakukannya complaiment oleh konsumen pengguna jasa Tiki. Diakses dari Mediakonsumen.com Tari Lestari menceritakan pengalamannya yang mengirimkan barang berupa cookies sebaganyak 8 Toples dengan destinasi Tanjung Selor Ke Metro Lampung, barang tersebut dikirimkan tersebut menggunakan Jasa Pengiriman Reguler dengan estimasi waktu 4-5 hari. ${ }^{2}$ Barang tersebut diterima oleh konsumen dalam keadaan 5 toples dalam keadaan baik sedangkan 3 toples pecah, sehingga pasca dilakukannya complaiment pihak Costumer Service menjawab bahwa barang yang dikirimkan tersebut memang dalam keadaan buruk ketika dikirimkan, dengan paket yang tidak dibungkus secara benar. Padahal Ida Bagus Bayu Kumara menjelaskan pada skripsinya bahwa perpindahan barang yang dilakukan menggunakan jasa ekspedisi seharusnya

1 Erni Setyowati dan Wiyadi, 2016, "Pengaruh Kualitas Pelayanan, Harga, dan Citra Merek Terhadap Loyalitas Pelanggan dengan Kepuasan Pelanggan Sebagai Variabel Pemediasi", Jurnal Ekonomi Managemen Sumber Daya, Program Studi Magister Managemen Universitas Surakarta, Volume 18, Nomot 2, h. 102.

2 Tari Lestari, 2018, "Pelayanan Tiki Yang Mengecewakan", diakses dari mediabaca.com, pada tanggal 31 Agustus 2018, pukul 17.03 WITA. 
bersifat statis atau diam. ${ }^{3}$ Complaiment yang telah diberikan tersebut dikembalikan kepada konsumen dengan menitikberatkan kesalahan tersebut pada konsumen itu sendiri.

PT. Citra Van Titipan Kilat memiliki kebijakannya sendiri yang dapat diakses pada ketentuan dan syarat-syarat penggunaan butir 10 bahwa ketika barang yang dikirim tersebut tidak sesuai dengan pelayanan yang ditawarkan maka shipper atau pengguna jasa tersebut dapat mengajukan klaim 5 (lima) hari dinas terhitung sejak pertama kali barang diterima. Pelayanan yang ditawarkan oleh Tiki sendiri meliputi:4 Same Day Sercive yang memungkinkan barang sampai pada tangan consignee pada hari yang sama dengan hari ketika barang tersebut dikirim; Over Night Service yang merupakan layanan pengiriman barang dengan tempo waktu satu malam; Two Days Service yakni pengiriman barang dengan estimasi waktu dua hari; Holiday Delivery Service yang memungkinkan pengiriman barang pada hari libur; Reguler Service yang memungkinkan barang sampai ke tangan konsumen dalam waktu 7 (tujuh) hari; Economy Service yakni pengiriman barang dengan biaya murah; International Service yang memberikan akses pengiriman barang internasional dengan estimasi harga yang kompetitif serta Trucking Service yang memudahkan pengiriman barang dengan berat diatas $10 \mathrm{~kg}$.

Pelayanan Over Night Service juga dipertanyakan eksistensinya sebab jasa pengiriman satu malam yang dimaksudkan tersebut tidak sepenuhnya diterapkan dengan maksimal. Adakalanya ketika barang tersebut memakan waktu 2-3 hari untuk sampai pada tangan konsumen. Biaya pengiriman Over Night Service yang telatif lebih tinggi dari paket pengiriman lainnya menjadikan sebuah persoalan tersendiri yang membuat konsumen cenderung bersifat kritis. Over Night Service menentukan bahwa produk yang ditawarkan tersebut akan sampai ke tangan konsumen dalam jangka waktu satu malam. Tiki

3 Ida Bagus Bayu Kumara, 2018, "Pertanggungjawaban Penyedia Jasa Pengiriman Barang Dalam Hal Terjadi Kerusakan Obyek Pengangkutan oleh Tiki”, Skripsi, Fakultas Hukum Universitas Udayana, h. 29.

4 Titipan Kilat Indonesia, 2018, "Produk Tiki", Diakses dari https://tiki.id/about/produk, pada tanggal 31 Agustus 2018, pukul 17.27 WITA. 
sendiri tidak memiliki ketentuan khusus yang mengatur terkait Over Night Service selain ketentuan dan syarat-syarat penggunaan yang ditampilkan pada berandanya. Hal yang menjadi persoalan adalah sejauh mana penghitungan jangka pengiriman melalui penawaran jasa Over Night Service yang dilakukan oleh Tiki?

Menarik untuk dicermati bahwa persoalan yang diangkat tersebut didasarkan oleh pertimbangan bahwa perlindungan konsumen merupakan sebuah tonggak utama untuk melindungi konsumen dari monopoli keuntungan pelaku usaha. Maka dari itu, maka disusunlah jurnal berjudul "Pertanggung Jawaban Atas Kerusakan Barang Pada Jasa Ekspedisi Pelayanan Satu Malam Pada Perusahaan Tiki" dengan menggunakan variabel pelayanan satu malam pada perusahaan ekspediri PT. Citra Van Titipan Kilat sebagai obyek penelitian. 


\subsection{Rumusan Masalah}

(1) Bagaimanakah tanggung jawab atas kerugian terhadap jasa ekspedisi pelayanan satu malam apabila terjadi keterlambatan?

(2) Bagaimana bentuk penyelesaian atas kerugian dari jasa ekspedisi pelayanan satu malam itu?

\subsection{Tujuan Penulisan}

(1) Untuk mengetahui bentuk tanggung jawab yang diberikan kepada konsumen saat menggunakan jasa pengiriman tersebut.

(2) Untuk mengetahui bentuk ganti kerugian yang diberikan kepada konsumen saat menggunakan jasa pengiriman tersebut.

\section{Isi Makalah}

\subsection{Metode Penulisan}

Metode memegang peran penting dalam menentukan hasil akhir dari sebuah jawaban oleh karena itu, maka keikutsertaan metode dalam sebuah penyusunan karya tulis ilmiah sejatinya harus dipertimbangkan secara matang. ${ }^{5}$ Berkenaan dengan itu, penyusunan jurnal ini menggunakan metode penelitian hukum empiris untuk mencapai jawaban yang disusun. Penelitian hukum empiris atau sering disebut dengan penelitian yuridis-sosiologis bertujuan mengungkapkan hukum yang hidup dalam masyarakat melalui perbuatan yang dilakukan oleh masyarakat dibutuhkan data primer yaitu data yang diperoleh secara langsung dari responden. ${ }^{6}$ Penulisan ini menggunakan pendekatan perundang-undangan dan pendekatan fakta empiris yakni; melalui pendekatan melihat dan mengamati fakta-fakta yang ada di dalam masyarakat. Tehnik pengumpulan data dilakukan dengan wawancara secara terstruktur di dalam perusahaan Tiki.

\footnotetext{
${ }^{5}$ Tanjung, Bahdin Nur dan Ardial, H. 2005. "Pedoman Penulisan Karya Ilmiah (Proposal, Skripsi, dan Tesis), Dan Mempersiapkan Diri Menjadi Penulis Artikel IImiah". Kencana. Medan, h.34.

${ }^{6}$ Tanjung, Bahdin Nur dan Ardial, H. 2005. "Pedoman Penulisan Karya Ilmiah (Proposal, Skripsi, dan Tesis), Dan Mempersiapkan Diri Menjadi Penulis Artikel IImiah". Kencana. Medan.
} 


\section{Hasil dan Analisis}

\subsection{Tanggung jawab pelayanan satu malam pada perusahaan Tiki terhadap konsumen pengguna jasanya dalam hal terjadi keterlambatan barang}

Secara umum pengiriman barang adalah mempersiapkan pengiriman fisik barang dari gudang ketempat tujuan yang disesuaikan dengan dokumen pemesanan dan pengiriman serta dalam kondisi yang sesuai dengan persyaratan penanganan barangnya. Dengan ini konsumen dengan penyedia jasa akan melakukan kesepakatan pengiriman barang dimana konsep kesepakatan itu diatur secara khusus di dalam pasal 1320 Kitab UndangUndang Hukum Perdata yang disebut KUHPerdata merupakan sebuah unsur wajib dalam sebuah perjanjian. Dalam hal ini turut diterapkan pada perusahaan Tiki melalui jasa pelayanan satu malam (over night service) sebagai bentuk adanya kesepakatan antara konsumen dengan penyedia jasa pengiriman,untuk itu maka pihak Tiki yang akan bertanggung jawab pasca dilakukannnya pengiriman barang tersebut.

Berdasarkan data yang diperoleh dari Wayan Mertayasa selaku staff pegawai Tiki Denpasar, Pelayanan yang ditawarkan oleh Tiki sendiri meliputi: Same Day Sercive yang memungkinkan barang sampai pada tangan consignee pada hari yang sama dengan hari ketika barang tersebut dikirim; Over Night Service yang merupakan layanan pengiriman barang dengan tempo waktu satu malam; Two Days Service yakni pengiriman barang dengan estimasi waktu dua hari; Holiday Delivery Service yang memungkinkan pengiriman barang pada hari libur; Reguler Service yang memungkinkan barang sampai ke tangan konsumen dalam waktu 7 (tujuh) hari; Economy Service yakni pengiriman barang dengan biaya murah; International Service yang memberikan akses pengiriman barang internasional dengan estimasi harga yang kompetitif serta Trucking Service yang memudahkan pengiriman barang dengan berat diatas 10 kg. ${ }^{7}$ Meskipun pelayanan yang diberikan cukup menarik akan tetapi penting untuk dipahami bahwa Tiki sebagai pelaku usaha yang berstatus sebagai perusahaan yang dibatasi oleh Undang-Undang Nomor 8 tahun 1999 tentang Perlindungan Konsumen bagi setiap aktifitas yang dilakukannnya. Menyikapi persoalan tersebut Jonathan Sawono dan Tutty Martadiredja menjelaskan bahwa dalam teori pemasaran, seorang merchant (istilah pelaku usaha yang

\footnotetext{
${ }^{7}$ Wawancara dengan bapak Wayan Mertayasa staff Tiki Denpasar
} 
digunakan dalam kerangka E-commerce) haruslah menjelaskan dengan rinci produk yang ditawarkannya. ${ }^{8}$

Berdasarkan hasil wawancara dengan konsumen yaitu saudara adit dan saudari tasya, hak mereka berupa jaminan dalam hal keamanan barang yang mereka kirim melalui jasa Tiki sudah diperoleh walaupun belum maksimal. Mereka lebih mempermasalahkan kenyamanan dalam menggunakan jasa Tiki diantaranya sering terjadi keterlambatan untuk barang yang mereka kirim atau terima sehingga bagi mereka yang memiliki online shop hal ini sangat merugikan karena sering mendapat keluhan dari para konsumen mereka. Tidak jarang juga setiap paket kiriman barang mereka sering mengalami cacat atau perubahan fisik diantaranya kardus paketan mereka saat diterima mengalami kerusakan yang mengakibatkan isi dari paketan tersebut juga mengalami kerusakan yang mengakibatkan kerugian bagi mereka. ${ }^{9}$

Telah ditentukan di dalam Pasal 19 ayat(1) Undang-undang Nomor 8 tahun 1999 ; pelaku usaha bertanggung jawab memberikan ganti rugi atas kerusakan, pencemaran dan atau kerugian konsumen akibat mengkonsumsi barang atau jasa yang dihasilkan atau diperdagangkan. Dalam kerusakan barang belum tentu menjadi tanggung jawab penyedia jasa karena bisa saja barang tersebut sudah ada cacatnya sebelum diberikan kepada pengangkut untuk dikirim, dengan demikian sebelum dilakukan pengiriman biasanya pengangkut melakukan pengecekan terlebih dahulu sebelum dilakukan pengiriman barang untuk menghindari adanya klaim palsu dari pihak konsumen dalam hal ini penyedia jasa dapat menolak klaim dari konsumen apabila : 10

a. Cacat pada barang itu sendiri.

b. Kesalahan atau kealpaan pengirim atau ekspeditur.

c. Keadaan memaksa (overmacht,force majure).

Pada dasarnya semua hal menyangkut mengenai kerugian konsumen yang disebabkan oleh pihak perusahaan pengiriman barang sebagai pengangkut berkewajiban untuk memberi pertanggung jawaban atas kesalahan yang ditimbulkannya tetapi dalam hal ini ada batasan-batasan tertentu yang membatasi bahwa pihak pengangkut tidak bertanggung jawab atas kerugian tersebut. Perusahaan yang secara konsisten dalam jangka waktu panjang menjalankan tanggung jawab sosial perusahaannya akan membawa dampak

\footnotetext{
${ }^{8}$ Mariam Darus Badrulzaman, Kompilasi hukum perikatan, PT Citra Aditya Bakti, Bandung, 2001, hlm.21

${ }^{9}$ Wawancara pada tanggal 18 november 2018

${ }^{10}$ HMN Purwosutjipto, Pengertian Pokok-Pokok Hukum Dagang Indonesia 3 : Hukum Pengangkutan. (Jakarta : Penerbit Djambatan, 2003)
} 
positif bagi perusahaan dan dapat membuat masyarakat menerima kehadiran perusahaan. ${ }^{11}$ Secara teoritis pertanggung jawaban yang berdasarkan jenis hubungan atau peristiwa hukum yang dapat dibedakan menjadi: 12

a. Pertanggung jawaban atas dasar kesalahan yang dapat lahir karena terjadinya wanprestasi timbulnya perbuatan melawan hukum tindakan yang kurang hati-hati.

b. Pertanggung jawaban atas dasar resiko yaitu tanggung jawab yang harus dipikul sebagai risiko yang harus diambil oleh seseorang pengusaha atas kegiatan usahanya.

Khususnya Pelayanan Over Night Service juga dipertanyakan eksistensinya sebab jasa pengiriman satu malam yang dimaksudkan tersebut tidak sepenuhnya diterapkan dengan maksimal. Adakalanya ketika barang tersebut memakan waktu 2-3 hari untuk sampai pada tangan konsumen. Biaya pengiriman Over Night Service yang telatif lebih tinggi dari paket pengiriman lainnya menjadikan sebuah persoalan tersendiri yang membuat konsumen cenderung bersifat kritis. Tiki sendiri tidak memiliki ketentuan khusus yang mengatur terkait Over Night Service selain ketentuan dan syarat-syarat penggunaan yang ditampilkan pada berandanya. Keterlambatan ini jelas akan menimbulkan suatu kerugian terhadap konsumen yang telah membayar mahal pada pelayanan tersebut dengan adanya kesepakatan pengiriman hanya satu malam namun yang terjadi pengiriman tersebut, melewati batas waktu dan pihak Tiki belum memberikan pertanggungjawaban yang pasti terhadap pelayanan satu malam tersebut. Dengan demikian maka dapat disimpulkan bahwa pertanggung jawaban yang seharusnya di dapatkan oleh seorang pengguna jasa Tiki khususnya pelayanan satu malam adalah ganti rugi atas kerusakan barang ataupun kerugian yang dapat dialaminya akan tetapi pihak Tiki belum memberikan pertanggung jawaban yang pasti mengenai keterlambatan pengiriman yang telah disepakati bersama.

\subsection{Bentuk Penyelesaian Ganti Kerugian yang Layak Terhadap Complain Kerusakan Barang Jasa Ekspedisi Pelayanan Satu Malam Tiki.}

\footnotetext{
${ }^{11}$ Ida Ayu Sukihana ,(2017), Tanggung Jawab Perusahaan Dari Profit Menuju Stakeholders Oriented Studi CSR di Tabanan, Kertha Patrika,39(03), H. 5, URL; https://ojs.unud.ac.id/index.php/kerthapatrika/article/view/39984 , diakses Tanggal 18 November 2018

12 Janus Sidabalok, Hukum Perlindungan Konsumen Di Indonesia,(PT Citra Aditya Bakti,2006)
} 
Ida Bagus Bayu Kumara menjelaskan bahwa perlindungan konsumen di Indonesia terkhususnya di Provinsi Bali masih lemah, hal ini yang menjadi alasan mengapa peredaran barang masih dengan bebas dilaksanakan di Indonesia dan sepenuhnya belum mendapatkan pengawasan. ${ }^{13}$ Di Tahun 2015 melalui Survey yang dilakukan oleh Pusat Kebijakan Perdagangan dalam Negeri Indonesia disimpulkan bahwa lemahnya perlindungan konsumen didasarkan oleh faktor perencanaan yang masih belum efektif, pola interaksi antar perusahaan dan lembaga pelindung konsumen yang masih belum sinkron dan balance menjadi sebuah persoalan tersendiri bagi penegakan hukum di Indonesia. ${ }^{14}$ Menarik untuk dicermati bahwa ganti rugi menjadi sebuah sarana penegakan hukum penting untuk diefektifkan dalam rangka menjamin hak konsumen.

Menurut Pasal 1243 KUH Perdata, pengertian ganti rugi perdata lebih menitikberatkan pada ganti kerugian karena tidak terpenuhinya suatu perikatan, yakni kewajiban pelaku usaha untuk mengganti kerugian konsumen akibat kelalaian pihak pelaku usaha melakukan wanprestasi ganti rugi tersebut meliputi:

a. Ongkos atau biaya yang telah dikeluarkan

b. Kerugian yang sesungguhnya karena kerusakan, kehilangan benda milik konsumen akibat kelalaian pihak pelaku usaha.

c. Bunga atau keuntungan yang diharapkan.

Masalah yang sering timbul dan menjadi kendala dalam perusahaan pengiriman barang terjadi karena adanya keterlambatan pengiriman barang kerusakan dan kehilangan dalam pengiriman barang oleh Tiki yang mengakibatkan kerugian terhadap konsumen. Konsumen merasa dirugikan karena pihak penanggung jawab Tiki tidak memberikan konfirmasi atas keterlambatan yang terjadi, selain keterlambatan Tiki juga sering tidak teliti dalam pengiriman barang yang mengakibatkan kerusakan barang. Oleh karena itu dalam pelaksanaan perjanjian pengiriman barang, tidak selamanya berjalan secara lancar. Berdasarkan teori-teori hukum konsumen sebagai pihak yang dirugikan diberikan hak untuk meminta ganti kerugian kepada pelaku usaha. ${ }^{15}$

\footnotetext{
${ }^{13}$ Ida Bagus Bayu Kumara, Op.cit, h. 21.

${ }^{14}$ Pusat Kebijakan Perdagangan Dalam. 2015. “Analisis Evaluasi Peredaran Barang dan Jasa”. Kementerian Perdagangan Republik Indonesia. Jakarta.

${ }^{15}$ Mariam Darus Badrulzaman, Kompilasi hukum perikatan, PT Citra Aditya Bakti, Bandung, 2001, hlm.21
} 
Berdasarkan data yang diperoleh dari Wayan Mertayasa PT.Citra Van Titipan Kilat memiliki kebijakannya sendiri yang dapat diakses pada ketentuan dan syarat-syarat penggunaan butir 10 bahwa ketika barang yang dikirim tersebut tidak sesuai dengan pelayanan yang ditawarkan maka shipper atau pengguna jasa tersebut dapat mengajukan klaim 5 (lima) hari dinas terhitung sejak pertama kali barang diterima. ${ }^{16}$

Ganti rugi sebagai tanggung jawab pelaku usaha juga diatur dalam Pasal 19 UU perlindungan konsumen yakni berupa memberikan sejumlah uang ataupun mengganti barang sejenis lainnya. Selain mempunyai hak-hak yang harus dipenuhi pelaku usaha juga mempunyai kewajiban-kewajiban yang harus dilakukan. Kewajiban pelaku usaha tersebut diatur dalam Pasal 7 huruf f dan huruf g undang-undang nomor 8 tahun 1999 tentang perlindungan konsumen yang menyebutkan bahwa itu kewajiban pelaku usaha. ${ }^{17}$ Mengenai ganti rugi yang akan diberikan, sebelumnya konsumen harus melakukan pengajuan klaim ganti rugi atas kerusakan barang terhitung 5 (lima) hari dinas sejak barang tersebut dikirimkan. Menanggapi klaim kerusakan tersebut, untuk barang yang tidak diasuransikan maka Tiki hanya akan mengganti sebesar 10 kali harga pengiriman atau tidak melampaui harga Rp.3.000.000,00 (tiga juta rupiah) sedangkan apabila barang diasuransikan maka penggantian tersebut akan dilakukan dengan membayar sebesar harga barang yang diasuransikan tersebut. Rusmawati menjelaskan bahwa dalam sengketa konsumen, gugatan yang hendak diberikan terbilang lemah sebab prinsip kurang hati-hati atau negligence yang sering dilakukan oleh konsumen sehingga melemahkan haknya ketika berhadapan di depan hukum bersama pelaku usaha. ${ }^{18}$

Menarik untuk dicermati dalam beberapa kasus sebagaimana telah diungkapkan di latarbelakang, dijelaskan bahwa klaim ganti rugi yang dilakukan terhadap perusahaan Tiki di Indonesia tidak memberikan kepastian hukum. Seperti halnya dengan kasus complaiment diakses dari Mediakonsumen.com Tari Lestari menceritakan pengalamannya yang mengirimkan barang berupa cookies sebaganyak 8 Toples dengan destinasi Tanjung Selor Ke Metro Lampung, barang tersebut dikirimkan tersebut menggunakan Jasa Pengiriman Reguler dengan estimasi waktu 4-5 hari.

\footnotetext{
${ }^{16}$ Wawancara dengan bapak Wayan Mertayaa staff Tiki Denpasar

${ }^{17}$ Ni Komang Ayu Nira Relies Rianti (2017), Tanggung Jawab Pelaku Usaha Terhadap Konsumen Dalam Hal Terjadinya Shortweighthing Dari Undang-Undang Ri No 8 Tahun 1999 Tentang Perlindungan Konsumen, Jurnal Magister Hukum Udayana, 06(04), H. 7, URL; https://ojs.unud.ac.id/index.php/jmhu/article/view/37177, diakses Tanggal 18 November 2018

${ }^{18}$ Rosmawati. 2015. "Pokok-Pokok Hukum Perlindungan Konsumen”. Konsumen. Palembang, h. 45.
} 
Barang tersebut diterima oleh konsumen dalam keadaan 5 toples dalam keadaan baik sedangkan 3 toples pecah, sehingga pasca dilakukannya complaiment pihak Costumer Service menjawab bahwa barang yang dikirimkan tersebut memang dalam keadaan buruk ketika dikirimkan, dengan paket yang tidak dibungkus secara benar. Padahal Ida Bagus Bayu Kumara menjelaskan pada skripsinya bahwa perpindahan barang yang dilakukan menggunakan jasa ekspedisi seharusnya bersifat statis atau diam. Complaiment yang telah diberikan tersebut dikembalikan kepada konsumen dengan menitikberatkan kesalahan tersebut pada konsumen itu sendiri. Menyikapi persoalan tersebut terdapat kebijakan dari tiki yang melepas kewajiban dari pelaku usaha untuk melakukan ganti rugi dinilai dapat melemahkan hak dari seorang konsumen. Di dalam Pasal 4 UU Perlindungan Konsumen telah menetapkan salah satu hak dari konsumen yakni untuk mendapatkan jaminan atas keamanan dan keselamatan barangnya agar terhindar dari kerugian fisik maupun psikis. Dengan demikian, maka dapat disimpulkan bahwa ganti rugi yang diberikan oleh perusahaan Tiki terhadap klaim kerusakan barang dan keterlambatan adalah melalui klaim dengan memberikan ganti rugi berupa uang atau tindakan lain dengan itikad baik antara kedua belah pihak, namun perusahaan Tiki belum mencerminkan kepastian hukum sebagaimana dimaksud dalam Undang-Undang Perlindungan Konsumen, yang melepas tanggung jawab ganti rugi yang menitikberatkan pada kesalahan konsumen itu sendiri.

\section{Penutup}

\subsection{Kesimpulan}

Berkenaan dengan pembahasan diatas, maka penyusunan jurnal ini berkesimpulan bahwa

(1) Tanggung jawab yang dilakukan oleh Tiki dalam hal menawarkan jasa pengirimannya masih perlu dibenahi kembali. Tanggung jawab yang dimaksudkan adalah mampu memberikan kejelasan kepada konsumen sebagaimana yang diharapkan dengan dibentuknya UU Perkon dan peraturan lain dibawahnya. Disamping penjaminan terhadap kepastian hukum berdasar pada Undang-Undang Dasar 1945 dan UU Perkon, peraturan lain dibawahnya juga telah menentukan aspek kepastian sebagaimana dimaksudkan tersebut. 
Tiki harus memperjelas prosedur pengirimannya sehingga dapat mencerminkan sebuah kepastian hukum yang menjamin pertangung jawaban apabila ingin menjaga loyalitas dari konsumen dan pengguna setia jasa pengirimannya.

(2) Pengiriman yang dilakukan melalui jasa perusahaan Tiki dalam hal melakukan pengirimannya masih perlu dibenahi. Masalah yang sering timbul dan menjadi kendala dalam perusahaan Tiki terjadi karena adanya keterlambatan pengiriman dan kerusakan barang yang mengakibatkan kerugian yang dialami oleh konsumen. Di dalam kegiatan pengiriman barang tersebut telah diatur pada KUHPerdata,UU Perlindungan Konsumen serta peraturan lainnya bahwa pelaku usaha wajib memberikan ganti rugi terhadap kerugian yang di dapat oleh konsumen karena kelalaian dari pihak pengirim barang itu. Namun ketika diajukan nya complaiment yang dilakukan oleh konsumen, pihak perusahaan tidak memberikan kepastian ganti rugi dan menitikberatkan kesalahan pada konsumen itu sendiri.

\subsection{Saran}

(1) Tiki perlu untuk memperjelas produk yang ditawarkannya khususnya pada jasa pelayanan satu malam (over night service) dari segi waktu, kualitas, keamanan serta aspek lain yang dapat menjamin kepastian hukum serta pertanggung jawaban yang dimaksud dalam UU Perkon.

(2) Aspek pertanggung jawaban dan ganti rugi perlu diperjelas kembali untuk membenahi kebijkan yang ada sebelumnya. Kerusakan ataupun complaiment yang diberikan kepada Tiki seharusnya bukan menjadi sarana untuk merugi akan tetapi penting dimaknai sebagai bagian dari pembaharuan perusahaan menjadi lebih baik dan menjaga loyalitas konsumen. 


\section{DAFTAR PUSTAKA}

\section{Buku}

HMN Purwosutjipto, Pengertian Pokok-Pokok Hukum Dagang Indonesia 3 : Hukum Pengangkutan. (Jakarta : Penerbit Djambatan, 2003)

Mariam Darus Badrulzaman, Kompilasi hukum perikatan, PT Citra Aditya Bakti, Bandung, 2001, hlm.21

Janus Sidabalok, Hukum Perlindungan Konsumen Di Indonesia,(PT Citra Aditya Bakti,2006)

Muladi. 2004. "Hak Aasi Manusia, Hakekat, Konsep dan Implikasinya dalam Perspektif Hukum dan Masyarakat”. Refika Aditama. Semarang.

Negeri, Pusat Kebijakan Perdagangan Dalam. 2015. "Analisis Evaluasi Peredaran Barang dan Jasa”. Kementerian Perdagangan Republik Indonesia. Jakarta.

Rosmawati. 2015. "Pokok-Pokok Hukum Perlindungan Konsumen”. Konsumen. Palembang.

Sarwono, Jonathan dan Martadirtedja, Tutty. 2008. "Teori E-Commerce, Kunci Sukses Perdagangan di internet”. Gava Media Yogyakarta Press. Bandung.

Susanti, Dyah Ochtorina dan Efendi, A'an. 2013. "Penelitian Hukum, Legal Research”. Sinar Grafika. Jember.

Tanjung, Bahdin Nur dan Ardial, H. 2005. "Pedoman Penulisan Karya Ilmiah (Proposal, Skripsi, dan Tesis), Dan Mempersiapkan Diri Menjadi Penulis Artikel Imiah”. Kencana. Medan.

\section{Jurnal dan Skripsi}

Kumara, Ida Bagus Bayu. 2018. "Pertanggungjawaban Penyedia Jasa Pengiriman Barang Dalam Hal Terjadi Kerusakan Obyek Pengangkutan oleh Tiki”. Skripsi. Fakultas Hukum Universitas Udayana. 
Setyowati, Erni dan Wiyadi. 2016. "Pengaruh Kualitas Pelayanan, Harga, dan Citra Merek Terhadap Loyalitas Pelanggan dengan Kepuasan Pelanggan Sebagai Variabel Pemediasi”. Jurnal Ekonomi Managemen Sumber Daya. Program Studi Magister Managemen Universitas Surakarta. Volume 18. Nomor 2.

Ida Ayu Sukihana ,(2017), "Tanggung Jawab Perusahaan Dari Profit Menuju Stakeholders Oriented Studi CSR di Tabanan", Kertha Patrika,39(03), H. 5, URL; https://ojs.unud.ac.id/index.php/kerthapatrika/article/view/39984 , diakses Tanggal 18 November 2018.

Ni Komang Ayu Nira Relies Rianti (2017), "Tanggung Jawab Pelaku Usaha Terhadap Konsumen Dalam Hal Terjadinya Shortweighthing Dari UndangUndang Ri No 8 Tahun 1999 Tentang Perlindungan Konsumen”, Jurnal Magister Hukum Udayana, 06(04), H. https://ojs.unud.ac.id/index.php/jmhu/article/view/37177, diakses Tanggal 18 November 2018

\section{Bahan Internet}

Tari Lestari, 2018, "Pelayanan Tiki Yang Mengecewakan", diakses dari mediabaca.com, pada tanggal 31 Agustus 2018, pukul 17.03 WITA.

Titipan Kilat Indonesia, 2018, "Produk Tiki", Diakses dari https://tiki.id/about/produk, pada tanggal 31 Agustus 2018, pukul 17.27 WITA.

\section{Bahan Hukum}

Kitab Undang-Undang Hukum Perdata.

Undang-Undang Nomor 8 Tahun 1995 Tentang Pasar Modal

Undang-Undang Nomor 8 Tahun 1999 tentang Perlindungan Konsumen

Undang-Undang Nomor 32 Tahun 2002 tentang Penyiaran

Peraturan Pemerintah Republik Indonesia Nomor 59 Tahun 2001 tentang Lembaga Perlindungan Konsumen Swadaya Masyarakat 